\title{
Perspektif, Pengetahuan dan Sikap Masyarakat terhadap Pandemi Covid-19
}

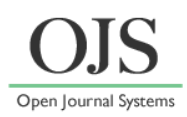

Eka Kartikawati

Program Studi Pendidikan Biologi, Universitas Muhammadiyah Prof. Dr. Hamka, Jakarta

Email: eka.kartikawati@uhamka.ac.id

DOI: https://doi.org/10.33369/pendipa.5.2.218-224

\begin{abstract}
The Covid-19 pandemic, needs to be faced with several scientific and non-scientific attitudes, it will certainly circulate in various circles of society as part of the attitude of thinking to know and understand the pandemic. Be it knowledge and attitude. The goal is to analyze the community in the face of the Covid19 pandemic. The method is descriptive, describing according to the situation with a questionnaire survey distributed via google form. The results are answers to questions about knowledge that discuss what is known about Covid-19, namely more than $75 \%$ of respondents answered knowing about the causes, spread, symptoms and prevention. This is because the information about Covid-19 always appears every day and from the start of the outbreak, the information provided is always updated, especially from the government and information through colleagues so that more than 75\% of the public know about Covid-19 in detail, both in terms of causes, spread, symptoms to prevention. a lot of information about covid-19 from various media obtained by various circles of society And only a small part do not know this.
\end{abstract}

Keywords: Knowledge, scientific attitude, coronavirus, Covid-19.

\begin{abstract}
ABSTRAK
Pandemi Covid-19, perlu dihadapi secara ilmiah dan non ilmiah masyarakat karena hal tersebut merupakan bagian sikap berpikir untuk mengetahui dan memahami pandemi tersebut. Baik itu pengetahuan dan sikap perilakunya. Tujuannya untuk menganalisis masyarakat dalam menghadapi pandemic covid-19. Metodenya adalah deskriptif, menggambarkan sesuai dengan keadaan dengan survei angket yang disebarkan melalui google form. Hasilnya jawaban dari pertanyaan mengenai pengetahuan yang membahas tentang apa yang diketahui mengenai covid-19 yaitu lebih dari 75\% responden menjawab mengetahui tentang penyebab, penyebaran, gejala dan pencegahannya. Hal ini dikarenakan karena pemberitaan informasi mengenai covid-19 tersebut setiap hari selalu muncul dan dari awal wabah ini selalu update informasi yang diberikan khususnya dari pemerintahan dan informasi melalui sejawatnya sehingga masyarakat lebih dari $75 \%$ mengetahui mengenai covid-19 secara rinci baik dari segi penyebab, penyebaran, gejala hingga pencegahannya. banyak informasi-informasi mengenai covid-19 dari berbagai media yang diperoleh oleh berbagai kalangan masyarakat Dan hanya sebagian kecil yang tidak mengetahui pengetahuan.
\end{abstract}

Kata kunci: Pengetahuan, sikap ilmiah, virus corona, Covid-19.

\section{PENDAHULUAN}

Pandemi COVID-19 adalah suatu peristiwa penyebaran penyakit covid 2019 di seluruh dunia. Penyakit ini disebabkan oleh virus corona. Penyebaran pandemi Covid-19 sangat bergerak cepat setiap harinya(World Health Organization, 2020). Dalam laman harian kompas menyatakan bahwa Tingkat mortalitas persebaran virus corona di Indonesia termasuk yang tertinggi di
Asia Tenggara $(8,46 \%)$ akibat kegigihan sikapsikap non-ilmiah menurut Prof. H. Masdar Hilmy Guru Besar dan Rektor UIN Sunan Ampel Surabaya.

Pandemi Covid-19, perlu dihadapi dengan beberapa sikap-sikap baik ilmiah dan non ilmiah pastilah akan beredar di berbagai kalangan masyarakat sebagai bagian sikap berpikir untuk mengetahui dan memahami pandemi tersebut 
(Sardinah et al., 2012). konstruksi sikap-sikap ilmiah tidak selalu berhubungan langsung dengan bagian penyebab atau penyebarannya(Setiati \& Azwar, 2020). Konstruksi non-ilmiah tersebut justru akan menjadikan penyebaran pandemi tersebut semakin buruk. Maka dari itu, diperlukan sikap kerendahhatian dari berbagai kalangan masyarakat untuk mengetahui pengetahuan-pengetahuan apa saja sertbeberapa sikap yang dapat memberikan penanganan peristiwa pandemi Covid-19 tersebut. Selain itu masyarakat juga perlu mengetahui dampak yang akan diperoleh dari pengetahuan serta sikap yang memberikan dampak baik atau buruk sebagai pilihan dari kalangan itu sendiri (Astika et al., 2013). Hal inilah yang ingin peneliti lihat seberapa besar perspektif masyarakat terhadap pandemi covid 19 ini yang di lihat dari beberapa aspek seperti pengetahuan, sikap dan perilaku.

\section{METODE PENELITIAN}

Metode yang digunakan dalam penelitian ini adalah metode deskriptif dengan pendekatan kuantitatif. Penelitian deskriptif dilakukan dengan tujuan untuk mendiskripsikan atau menggambarakan fakta-fakta mengenai populasi secara sistematis, dan akurat. Dalam penelitian deskriptif fakta-fakta hasil penelitian disajikan apa adanya (metode penelitian kuantitatif, kualitatif,dan $R \& D, 2016)$

Penelitian ini dilakukan pada masyarakat umum yang terdiri dari beberapa kalangan pendidik, pelajar, karyawan, wiraswasta dan ibu rumah tangga. Waktu penelitian pada tahun ajaran 2019/2020 pada bulan juni sampai agustus.

\section{HASIL DAN PEMBAHASAN}

Hasil penelitian mengenai perspektif sikap ilmiah masyarakat terhadap pandemi covid 19 diperoleh sebanyak 128 responden dari berbagai kalangan, diantaranya yaitu Dosen, guru/ pengajar, mahasiswa, siswa, staff/karyawan, wiraswasta dan umum. Data responden yang mengisi kuesioner terperinci yaitu $81,3 \%$ perempuan dan $18,8 \%$ laki-laki dari jumlah total keseluruhan 128 responden. Hasilnya jawaban dari pertanyaan mengenai pengetahuan yang membahas tentang apa yang diketahui mengenai covid-19 yaitu lebih dari $75 \%$ responden menjawab mengetahui tentang penyebab, penyebaran, gejala dan pencegahannya. Hal ini dikarenakan karena pemberitaan informasi mengenai covid-19 tersebut setiap hari selalu muncul dan dari awal wabah ini selalu update informasi yang diberikan khususnya dari pemerintahan dan informasi melalui sejawatnya sehingga masyarakat lebih dari $75 \%$ mengetahui mengenai covid-19 secara rinci baik dari segi penyebab, penyebaran, gejala hingga pencegahannya. banyak informasi-informasi mengenai covid-19 dari berbagai media yang diperoleh oleh berbagai kalangan masyarakat. Informasi-informasi mengenai covid-19 tersebut berasal dari berbagai media yang diperoleh karena media massa akan dapat menciptakan kanekaragaman di masyarakat. Rata-rata diatas $75 \%$ responden pun juga diperoleh mengenai pengetahuan tentang segala sesuatu yang berhubungan dengan pandemi covid 19 walaupun ada beberapa persen hanya yang mengetahui bagian-bagian tertenntu saja seperti fungsinya atau definisinya saja. Dan hanya sebagian kecil yang tidak mengetahui pengetahuan tersebut.. Hal ini dikarenakan adanya pemberitaan secara rutin dan bertahap sehingga menyebabkan masyarakat akan mengalami suatu perubahan yakni dalam suatu nilai, pemikiran dan tindakan dalam keseharian masyarakat (Sohana Abdul Hamid, 2016).

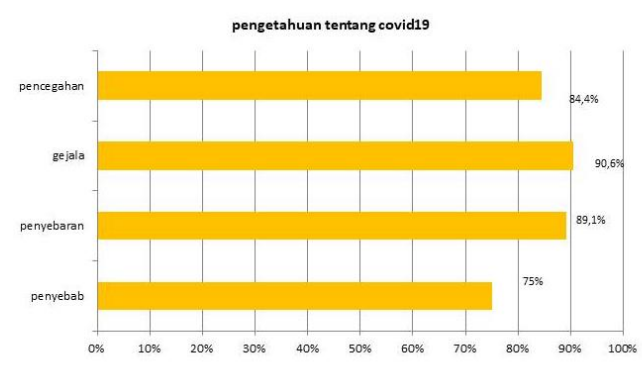

Gambar 1. Persentase pengetahuan masyarakat tentang covid-19

Pertanyaan selanjutnya mengenai tentang bagaimana sikap responden, apabila ada orang yang mengajak bersalaman pada saat bertemu. Hasil yang diperoleh yaitu $56,3 \%$ responden menolak bersalaman dengan siapapun, $35,9 \%$ 
memilih-milih orang dan 7,8\% tetap bersalaman dengan siapapun. The Liang Gie (Ertanti, 2016)mengemukakan bahwa sikap ilmiah adalah suatu kecenderungan pribadi seorang ilmuwan untuk berperilaku atau memberikan tanggapan dalam hal-hal tertentu sesuai dengan pemikiran ilmiahnya atau tidak bertentangan dengan citra keilmuwan pada umumnya

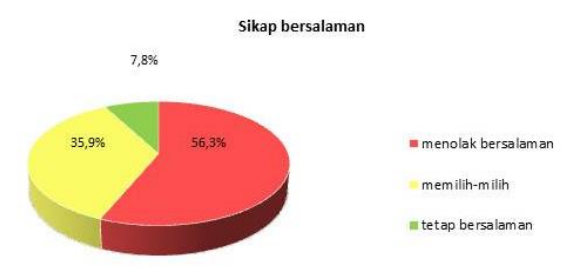

Gambar 2. Persentase sikap masyarakat tentang covid-19

Pertanyaan berikutnya mengenai apa yang akan dilakukan jika menghadapi orang yang jarang ditemui, 95,3\% menjawab akan jaga jarak, 3,1\% tetap bertemu dan bersalaman dan $1,6 \%$ tidak mau bertemu.

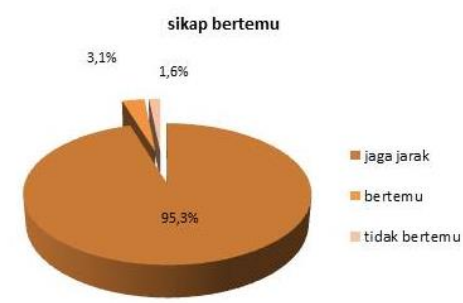

Gambar 3. Persentase sikap bertemu

Mengenai sikap mereka dihadapkan pada orang yang mengajak bersalaman pada saat bertemu. Hasilnya yang diperoleh yaitu 56,3\% responden menolak bersalaman dengan siapapun, hal ini karena masyarakat lebih antisipasi dalam menghadapi covid-19 tersebut walaupun $35,9 \%$ memilih-milih orang untuk bersalaman juga. Hal lainnya mengenai apa yang akan dilakukan jika menghadapi orang yang jarang ditemui, $95,3 \%$ responden menjawab akan jaga jarak dan menggunakna protocol kesehatan(Kementrian Kesehatan Republik Indonesia, 2020). Hal ini dikarenakan setiap manusia memiliki rasa antisipasi dan kekhawatiran masyarakat yang tinggi untuk menghindari bahaya covid-19 tersebut, maka memang sangat diperlukan suatu kebijakan dari pemerintahan seperti PSBB atau Lockdown sebagai upaya mencegah dan memtus rantai penyebaran virus covid-19 (Yunus \& Rezki, 2020). Pembatasan sosial berskala besar di indonesia juga merupakan penanggulangan pandemi covid-19 yang sangat efektif (Thorik, 2020).

\section{KESIMPULAN}

Kesimpulan dari penelitian ini bahwa $75 \%$ responden sudah mengetahui tentang penyebab, penyebaran, gejala dan pencegahannya, hal ini disebabkan adanya informasi-informasi mengenai covid-19 di berbagai media sehingga masyarakat mengalami suatu perubahan pengetahuan dan sikapnya.

\section{DAFTAR PUSTAKA}

Astika, I. K. U., Suma, I. K., \& Suastra, I. W. (2013). Pengaruh Model Pembelajaran Berbasis Masalah Terhadap Sikap Ilmiah Dan Keterampilan Berpikir Kritis. E-Journal Program Pascasarjana Universitas Pendidikan Ganesha.

Ertanti, D. W. (2016). Penerapan model pembelajaran kooperatif tipe nht pada mata pelajaran ipa untuk meningkatkan prestasi belajar siswa kelas v sekolah dasar. Modeling: Jurnal Program Studi PGMI.

Kementrian Kesehatan Republik Indonesia. (2020). Pedoman Pencegahan dan Pengendalian Coronavirus Disease (COVID19). In Germas.

Sardinah, Tursinawati, \& Noviyanti, A. (2012). Relevansi Sikap Ilmiah Siswa Dengan Konsep Hakikat Sains Dalam Pelaksanaan Percobaan Pada Pembelajaran Ipa Di Sdn Kota Banda Aceh. Jurnal Pendidikan Serambi Ilmu.

Setiati, S., \& Azwar, M. K. (2020). COVID-19 and Indonesia. Acta Medica Indonesiana.

Sohana Abdul Hamid. (2016). Pengaruh Media 
Massa Terhadap Masyarkat. Journal of Social Sciences and Humanities.

metode penelitian kuantitatif, kualitatif,dan

R\&D, Alfabeta, cv. (2016).

Thorik, S. H. (2020). Efektivitas Pembatasan Sosial Berskala Besar Di Indonesia Dalam Penanggulangan Pandemi Covid-19. Jurnal Adalah: Buletin Hukum Dan Keadilan.

World Health Organization. (2020). WHO

Timeline COVID-19. World Health Organization .

Yunus, N. R., \& Rezki, A. (2020). Kebijakan Pemberlakuan Lock Down Sebagai Antisipasi Penyebaran Corona Virus Covid-19. SALAM: Jurnal Sosial Dan Budaya Syar-I. https://doi.org/10.15408/sjsbs.v7i3.15083 